Коваль С. І., ст. викладач, Ковальчук Є. А., магістр з маркетингу (Національний університет водного господарства та природокористування, м. Рівне)

\title{
УПРАВЛІННЯ ЯКІСТЮ В СФЕРІ ТУРИСТИЧНИХ ПОСЛУГ
}

Якість туристичного продукту характеризується якістю послуг, що входять до його складу. При вивченні якості туристичних послуг виділяють три рівні: технічна, соціальна та якість навколишнього середовища. В умовах розвитку туристичної індустрії, обов'язковими вимогами є забезпечення безпеки життя і здоров'я; гарантія надання послуг; збереження майна туриста; охорона навколишнього середовища. Реалізація стратегії «управління якістю» може бути представлена в трьох варіантах: 1-й - формування якості управлінської діяльності у вищій і середній ланках управління; 2-й - формування якості управлінської діяльності в системі управління якістю; 3-й - формування якості на рівні технології реалізації туристських послуг. Для належного управління якістю продукту (послуги) в умовах конкурентного середовища і розширення ринків діяльності, в тому числі закордонних, компанії переходять на використання міжнародних стандартів, головним із яких є стандарт серії ISO 9000.

Ключові слова: управління якістю, стандарти, маркетингові інструменти, конкуренція, стратегічний маркетинг, конкурентне середовище.

Якість туристичного продукту характеризується якістю послуг, що входять до його складу, а також культурою обслуговування. Якість послуги залежить, як від об'єктивних факторів, так i суб'єктивних чинників. Об'єктивні - це рівень підготовленості туриста до поїздки, його поінформованість про країну. Суб'єктивні пов'язані з особистими характеристиками туриста, умовами його повсякденного життя, форс-мажорними обставинами. Регулювати суб'єктивні якості можна за допомогою професіоналізму працівників туристичної сфери, підготовленості місцевого населення до прийняття туристів тощо.

При вивченні якості туристичних послуг виділяють три рівні:

- технічна якість, що характеризується станом інфраструктури;

- соціальна якість, що передбачає належний рівень сервісу, 
професіоналізм персоналу;

- якість навколишнього середовища, яка забезпечується станом екології, рівнем життя населення.

В умовах розвитку туристичної індустрії, урізноманітнення і вдосконалення технологій надання туристичних послуг, обов'язковими вимогами до якості туристичних послуг є забезпечення безпеки життя і здоров'я; гарантія надання послуг, згідно путівки; збереження майна туриста, а також охорона навколишнього середовища.

Стандартизація - це діяльність, що спрямована на розробку і встановлення вимог, норм правил, характеристик як обов'язкових до виконання, так і тих, що носять рекомендаційний характер, за допомогою яких забезпечується право споживача на придбання послуг належної якості за прийнятну ціну, а також право на безпеку і комфортність туристичної послуги. Стандартизація може стосуватися, як самої сфери тур індустрії, так і її об'єктів - конкретних туристичних послуг.

Для забезпечення належного рівня обслуговування туристів, необхідно вирішити ряд наступних завдань, основними з яких $є$ :

1) встановлення номенклатури показників якості послуг і методів їх контролю;

2) забезпечення прогресивних технологій в процесі надання тур послуг;

3) встановлення вимог, що гарантують безпеку послуг, охорону здоров'я споживачів, своєчасність виконання зобов'язань зі сторони туроператора, ергономічність і естетичність послуг, належний рівень обслуговування;

4) встановлення вимог до сертифікації туристичних послуг;

5) забезпечення координації діяльності турпідприємств з підприємствами інших галузей, що беруть участь в процесах туристичноекскурсійного обслуговування;

6) забезпечення уніфікації та взаємозв'язку міжнародної та національної стандартизації з можливістю реалізації ї вимог на регіональному рівні [6].

Міжнародна організація зі стандартизації (ISO) визначає якість як сукупність властивостей і характеристик продукту, які надають йому здатність задовольняти певні потреби - вже конкретно визначені чи потенційно передбачувані [1].

Для створення технологій у сфері управління якістю $€$ міжнародні стандарти ISO серії 9000. Саме вони є тими директивними настановами, які беруться за основу при встановленні ідентичних норм до аналогічної продукції та послуг як в цілому у світі, так і у сфері туризму безпосередньо [2]. 
У загальному вигляді модель управління якістю туристичної фірми чи підприємства представляє собою кругообіг, в який включені: система цінностей самого підприємства, потреби споживачів, процеси системи управління якістю задля досягнення належного рівня задоволення самого споживача. Для розробки моделі, спрямованої на покращення якості послуг, що надаються туристичним підприємством, необхідно проаналізувати наступні основні критерії, а саме: систему управління персоналом, зовнішнє середовище підприємства, асортимент і якість безпосередньо самих послуг.

Аналіз асортименту послуг, що надаються турпідприємством, дозволяє виявити найбільш затребувані їх види, а також визначити динаміку обсягів їх реалізації і долю кожного виду туристичного продукту. Такий аналіз дозволяє чітко визначити, які туристичні послуги $\epsilon$ найбільш популярними серед клієнтів, і відповідно з цим розробити необхідні заходи щодо зміни асортиментної політики туристичного підприємства, або ж заходи, спрямовані на підвищення рівня якості цих послуг.

Для існування компанії в умовах ринкової економіки необхідно вміти створювати стабільно конкурентоспроможний продукт, який хотів б купувати споживач. При цьому, споживач повинен купувати цю продукцію на вільному ринку, керуючись своїми потребами і бажаннями. Основа конкурентоздатності продукту - його якість. Якість - це здатність продукту-товару чи продукту-послуги задовольняти потреби покупця. В цілому конкурентоспроможність складається 3 трьох основних компонентів: необхідна якість, ціна, оригінальність.

Якість продукту - це не тільки відповідний рівень технічної бази, технології, економіки, організації надання і культури, але і відповідний рівень професіоналізму і культури управлінських відносин. Досягнення необхідної якості пов'язано з постійним, динамічним процесом з удосконалення якості - «управління якістю».

Реалізація стратегії «управління якістю» може бути представлена в трьох варіантах:

1-й - формування якості управлінської діяльності у вищій і середній ланках управління;

2-й - формування якості управлінської діяльності в системі управління якістю;

3-й - формування якості на рівні технології реалізації (надання).

Без правильно визначених маркетингових цілей важко розробити ефективну маркетингову стратегію, затвердити дієву маркетингову політику і реалізувати маркетинговий план просування продукту. Стратегічні цілі в маркетингу $є$ основою кожного бізнесу, мають 
свою кваліфікацію і чіткий порядок формування.

Системний підхід передбачає, що першочергове значення отримує загальна якість управлінської діяльності, а потім - якість технології реалізації (надання), якщо розглядати сферу туристичної індустрії. Комплексна стратегія заснована на пріоритеті якості тих елементів надання тур послуг і управління ними, які безпосередньо впливають на якість продукту. Третій варіант - це локальний підхід, в якому основна увага приділяється технології реалізації послуг. Тому можна казати, що локальна стратегія $€$ найбільш розповсюдженою і методично добре розробленою; системний варіант тільки впроваджується і для нього існує набір стандартів як на технологію надання послуг, так і на систему якості продукту, як зазначалося вище, наприклад, ISO 9000. Системний підхід - це перспектива розвитку будь-якої компанії, фірми, організації чи підприємства.

Якість - це сукупність характеристик об'єкту, що відносяться до його здатності задовольняти встановлені чи передбачувані потреби. Якість інший раз інтерпретується, як «придатність до дії». Іїі оцінюють з точки зору функціональної приналежності, експлуатаційних характеристик, ступеня безпеки, надійності тощо.

Показники якості, визначені на реальному туристичному ринку як привабливі для сьогоднішнього покупця, характеризують нормативну якість, яка повинна бути закріплена в нормативній документації. Крім нормативної якості, існує перспективна якість, тобто якість, яку необхідно отримати в найближчому майбутньому, оскільки потреби споживачів змінюються, як наука і техніка, що постійно створюють нові інноваційні розробки, які дозволяють значно підвищити параметри якості продукту, в тому числі в туристичній сфері.

Якість продукту може бути визначена трьома способами:

1-й - за власною методикою фірми чи підприємства. Методика може базуватися на статистичних дослідженнях та інших параметрах зовнішніх і внутрішніх оцінок продукту;

2-й - по відношенню до якості певного зразка, прийнятого за еталон;

3-й - по відношенню до міжнародного чи національного стандарту.

Таким чином, кожний спосіб оцінки якості продукту має відповідну сферу ефективного використання.

Важливу роль у забезпеченні належного рівня продукту, що продукується підприємством, відіграє якість управлінської діяльності. Вона передбачає ї̈ відповідність загальноприйнятим вимогам і стандартам. 
Управлінська діяльність на підприємстві є складовою частиною системи управління. Елементи системи управління мають різну складність і ступінь розробки. Найбільш розробленими є параметри, що входять в основу будь-якої системи управління, - цілі і задачі діяльності, основні функції, організаційно-функціональні структури, інформаційне забезпечення.

Для належного управління якістю продукту в умовах конкурентного середовища і розширення ринків діяльності, в тому числі закордонних, підприємства переходять на використання міжнародних стандартів, головним із яких $є$ стандарт ISO 9000 (ISO - Міжнародна організація зі стандартизації). Він об'єднує три стандарти, характеристика яких наведена у табл. 1 [3; 4; 5].

Необхідно відмітити, що міжнародні стандарти серії ISO 9000 носять рекомендаційний характер і використовується при підготовці національних стандартів управління. Вони лише описують елементи, які повинна включати система якості, а не способи впровадження конкретним підприємством цих елементів. Дані стандарти містять характеристику лише тих мінімальних вимог, які необхідно виконати підприємству з точки зору доказів виробником своєї здатності дотримання якості при поставках продукції чи наданні послуг. У випадку прийняття його національними службами стандартизації, ISO 9000 отримує подвійну назву.

Кожний із стандартів $є$ моделлю для формування управлінських структур, відповідальних за забезпечення якості. Іншими словами, вони описують те, як керівництво організовує свої зусилля з управління якістю у масштабі всієї компанії (підприємства). Стандарт ISO 9000 - це документ, згідно якого третя сторона може проводити оцінку схеми роботи компаній зі своїми клієнтами.

У той же час міжнародні стандарти серії ISO 9000 це не тільки керівні вказівки щодо управління підприємством, але й хороший маркетинговий інструмент.

Як засвідчує практика, ціни на продукцію сертифікованих компаній інколи перевищують ціни конкурентів на 50\%. Це є тією перевагою, яку отримує підприємство, що інвестувало кошти чи певні засоби в побудову управління своєю діяльністю згідно вимог ISO 9000. 
Структурна характеристика стандартів серії ISO 9000

\begin{tabular}{|c|c|c|}
\hline Стандарт & Назва & Ціль \\
\hline $\begin{array}{c}\text { ISO 9001:2015 } \\
\text { (підлягає зміні } \\
\text { 15.09.2018) }\end{array}$ & $\begin{array}{l}\text { Система мене- } \\
\text { джменту якості - } \\
\text { Вимоги }\end{array}$ & $\begin{array}{l}\text { Націлений на просування вико- } \\
\text { ристання процесного підходу до } \\
\text { розробки, втілення і покращен- } \\
\text { ня результативності системи } \\
\text { менеджменту якості, зростання } \\
\text { задоволеності потреб спожива- } \\
\text { чів шляхом виконання його ви- } \\
\text { мог }\end{array}$ \\
\hline ISO 9002:2016 & $\begin{array}{l}\text { Система мене- } \\
\text { джменту якості - } \\
\text { Керівні вказівки } \\
\text { по використанню } \\
\text { ISO 9001:2015 }\end{array}$ & $\begin{array}{l}\text { Націлений на забезпечення ро- } \\
\text { зуміння внутрішніх і зовнішніх } \\
\text { факторів, суттєвих з точки зору } \\
\text { цілей і стратегічного напрямку } \\
\text { розвитку організації, які можуть } \\
\text { вплинути як позитивно, так і не-- } \\
\text { гативно на здатність організації } \\
\text { досягати запланованих у межах } \\
\text { їі системи менеджменту якості } \\
\text { результатів }\end{array}$ \\
\hline ISO 9004:2009 & $\begin{array}{l}\text { Управління з ме- } \\
\text { тою досягнення } \\
\text { стійкого успіху } \\
\text { організації - } \\
\text { Підхід з позиції } \\
\text { менеджменту } \\
\text { якості }\end{array}$ & $\begin{array}{l}\text { Націлений на досягнення ре- } \\
\text { зультативності в діяльності ор- } \\
\text { ганізації в інтересах усіх заціка- } \\
\text { влених сторін. }\end{array}$ \\
\hline
\end{tabular}

* розроблено автором

Основні причини прискореного розповсюдження використання серії стандартів ISO 9000 представлені в табл. 2.

На даний час, більшість країн світу привели свої національні стандарти відповідніо до міжнародної системи стандартизації, що значно спростило співпрацю на міжнародному ринку виробників і покупців продукції, які здійснюють свою діяльність на території різних країн. 
Таблиця 2

Основні причини використання серії стандартів ISO 9000*

\begin{tabular}{|l|c|}
\hline \multicolumn{1}{|c|}{ Причина } & $\begin{array}{c}\text { Рівень важли- } \\
\text { вості*, \% }\end{array}$ \\
\hline Утримання/збільшення долі ринку & 4,08 \\
\hline Підвищення ефективності & 4,07 \\
\hline Розглядатися в якості учасника тендеру & 3,98 \\
\hline Маркетингові вигоди & 3,96 \\
\hline Надання основи для торгової марки компанії & 3,66 \\
\hline Розробка зміни корпоративної культури & 3,22 \\
\hline
\end{tabular}

*розроблено автором

**цифри вказують середню важливість причини по 5-бальній шкалі

Враховуючи вимоги сьогодення щодо підвищення якості туристичного продукту і забезпечення безпеки споживачів, система Національних стандартів України адаптована (уніфікована) до системи міжнародних стандартів ISO.

Таким чином, можна зробити висновок, що управління якістю туристичних послуг - це процес, який включає в себе визначення характеру та обсягу вимог щодо обслуговування, оцінку фактичного рівня якості, розробку і здійснення заходів із забезпечення покращення системи менеджменту якості. Саме остання додає вартості як безпосередньо продукту, так і компанії в цілому. Тому вигода може бути отримана, якщо дана система чітко визначена й тісно пов'язана з інтересами компанії. При цьому політика держави у сфері туризму повинна бути направлена на створення сприятливих умов для успішного розвитку даної галузі з метою підвищення якості і рівня життя населення.

1. ISO 9000 как инструмент организационных изменений. URL: http://www.cfin.ru/management/is09000/qm_for_changes.shtml (дата звернення : 01.10.2018). 2. Международный стандарт ISO 9000. URL: http://pqmonline.com/assets/files/pubs/translations/std/iso-9001-2015-(rus).pdf (дата звернення : 01.10.2018). 3. Международный стандарт ISO 9001. URL: http://www.pqm-online.com/assets/files/pubs/translations/std/iso-90002015-(rus).pdf (дата звернення : 01.10.2018). 4. Международный стандарт ISO 9002. URL: http://www.vniis.ru/wp-content/uploads/2017/04/iso-ts9002-2016-rus.pdf (дата звернення : 01.10.2018). 5. Международный стандарт ISO 9004. URL: http://iso-management.com/wpcontent/uploads/2017/07/ISO-9004-2009.pdf (дата звернення : 01.10.2018). 6. Якість туристичного продукту. URL: http://library.if.ua/book/38/2552.html (дата звернення : 01.10.2018). 


\section{REFERENCES :}

1. ISO 9000 kak instrument orhanizatsyonnykh izmenenyi. URL: http://www.cfin.ru/management/iso9000/qm_for_changes.shtml_data zvernennia : 01.10.2018). 2. Mezhdunarodnыyi standart ISO 9000. URL: http://pqm-online.com/assets/files/pubs/translations/std/iso-9001-2015(rus).pdf (data zvernennia: 01.10.2018). 3. Mezhdunarodnyi standart ISO 9001. URL: http://www.pqm-online.com/assets/files/pubs/translations/std/iso9000-2015-(rus).pdf (data zvernennia : 01.10.2018). 4. Mezhdunarodnyi standart ISO $9002 . \quad$ URL: http://www.vniis.ru/wpcontent/uploads/2017/04/iso-ts-9002-2016-rus.pdf (data zvernennia: 01.10.2018). 5. Mezhdunarodnyi standart ISO 9004. URL: http://isomanagement.com/wp-content/uploads/2017/07/IS0-9004-2009.pdf (data zvernennia : 01.10.2018). 6. Yakist turystychnoho produktu. URL: http://library.if.ua/book/38/2552.html (data zvernennia: 01.10.2018).

Рецензент: д.е.н., проф. Мальчик М.В.(НУВГП)

Koval S. I., Senior Lecturer, Kovalchuk Ye. A., Master of Marketing (National University of Water and Environmental Engineering, Rivne)

\section{QUALITY MANAGEMENT IN THE FIELD OF TOURISM SERVICES}

The quality of the tourist product is characterized by the quality of the services included in its composition. In the study of quality tourist services there are three levels: technical quality, social quality, environmental quality. With the development of the tourism industry, the mandatory requirements are to ensure the safety of life and health; guarantee of service; the safety of the property of tourists; protection of the environment. The main options for a product quality management strategy are: formation of quality management activity in the higher and middle management, formation of quality management activities in the quality management system, formation of quality at the level of technology of implementation of tourist services formation of quality at the level of technology of implementation of tourist services In order to properly manage the quality of a product (service) in a competitive environment and expand the markets of activities, including overseas, companies are switching to the use of international standards, the most important of which is the standard of the ISO 9000 series.

Keywords: quality management, standards, marketing instruments, competition, strategic marketing, competition environment. 
Коваль С. И., ст. преподаватель, Ковальчук Е. А., магистр маркетинга (Национальный университет водного хозяйства и природопользования, г. Ровно)

\section{УПРАВЛЕНИЕ КАЧЕСТВОМ В СФЕРЕ ТУРИСТИЧЕСКИХ УСЛУГ}

Качество туристического продукта характеризуется качеством услуг, входящих в его состав. При изучении качества туристических услуг выделяют три уровня: техническое качество, социальное качество, качество окружающей среды. В условиях развития туристической индустрии, обязательными требованиями являются обеспечение безопасности жизни и здоровья; гарантия предоставления услуг; сохранность имущества туриста; охрана окружающей среды. Реализация стратегии «управление качеством» может быть представлена в трех вариантах: 1-й - формирование качества управленческой деятельности в высшем и среднем звеньях управления; 2-й - формирование качества управленческой деятельности в системе управления качеством; 3-й - формирование качества на уровне технологии реализации туристических услуг. Для надлежащего управления качеством продукта (услуги) в условиях конкурентной среды и расширения рынков деятельности, в том числе иностранных, компании переходят на использование международных стандартов, главным из которых является стандарт серии ISO 9000.

Ключевые слова: управление качеством, стандарты, маркетинговые инструменты, конкуренция, стратегический маркетинг, конкурентная среда. 